\title{
DETERMINING COMPETITIVE ADVANTAGE: THE ANALYTIC HIERARCHY PROCESS
}

\author{
Renata Korsakienė \\ Vilnius Gediminas Technical University, Sauletekio al. 11, LT-10223 Vilnius-40, Lietuva \\ E-mail: renatakorsa@takas.lt
}

Received 23 September 2004; accepted 2 November 2004

\begin{abstract}
Fundamental changes initiated by globalisation, new technologies, intensive competition, fluctuating demand of consumers, as well as economical and political changes encourage managers to be pro-active, take greater risks and choose innovative strategies. Besides that, a company's ability to gain competitive advantage becomes an urgent problem. However, the managers lack a clear approach to the determination of competitive advantage. That is why the article analyses some important aspects concerning company's competitive advantage and presents the results of the determination of company's competitive advantage by using analytic hierarchy process.
\end{abstract}

Keywords: competitive advantage, resource - based view, analytic hierarchy process.

\section{Introduction}

Fundamental changes initiated by globalisation, new technologies, intensive competition, fluctuating demand of consumers, as well as economical and political changes encourage managers to be pro-active, take greater risks and choose innovative strategies. Besides that, a company's ability to gain competitive advantage becomes an urgent problem.

In this situation research has revealed that competitive environment creates preconditions to companies to gain competitive advantage. However, another group of scientific works reveal that companies demonstrating better results possess something special and difficult to imitate. Therefore, it has been emphasised that unique capabilities and resources determine competitive advantage, and long-term advantage is maintained only when it is impossible to emulate the capabilities and resources of a company or to transfer them quickly to other companies. In the changing environment, companies willing to maintain competitive advantage and growth should constantly look for new resources and renew available resources. In this case, a consistent development of resources and capabilities helps a company to develop advantage that is difficult to imitate.

In its own turn, competitive advantage predetermines the achievement of such long-term results as better financial results, market share, greater value for consumers and stakeholders. Furthermore, long-term results affect resources and capabilities of a company as well as the environment, which the company works in. Results higher than those of competing companies influence the growth of financial resources and advancement of management skills directly. In their own turn, results achieved by one company affect the actions of its competitors, consumers' expectations and connections with suppliers.

However, it is necessary to point out that in the context of dynamic and uncertain environment, the managers lack a clear approach to the determination of competitive advantage; thus the goal of this paper is to analyse some important aspects concerning company's competitive advantage and to determine competitive 
advantage of a company working in electronics industry, by using analytic hierarchy process.

The object of this study is company's competitive advantage.

This research uses logical and comparative analysis and a method of analytic hierarchy process.

\section{Porter's Approach to Competitive Advantage}

Perpetual struggle against uncertainty in the business environment is considered one of organisations' main problems (Thompson, 1967). The definitions of environmental uncertainty could be divided into two groups: 1) based on how managers understand the business environment; 2) based on objective factors in the environment. The definitions attributed to the first group emphasise that companies react to changes in the environment depending on how their decisionmaking managers interpret them (Anderson \& Paine, 1975). In their own turn, while analysing uncertainty in the business environment in terms of objective factors, scholars try to prove that a weak empirical link exists between the managers' understanding and objective environmental factors.

It should be noted that these approaches to environmental uncertainty have a weak point. Because of this reason, some authors suggest that these two approaches should be combined. For instance, Milliken speaks of uncertainty in the business environment as of "an individual's perceived inability to predict something (the business environment) accurately" because of insufficient information" or the inability to "discriminate between relevant data and irrelevant data" (Milliken, 1987). Miller and Friesen treat the degree of dynamics and uncertainty in the environment as "the rate of change of innovation in the industry as well as the uncertainty or unpredictability of the actions of competitor or customer" (Miller \& Friesen, 1983). Uncertainty emerges in the environment when managers understand that the business environment or one of its factors are impossible to predict. In its own turn, the problem of uncertainty becomes urgent in an organisation when managers find it difficult to predict the influence that changes in the business environment have on their organisation. It should be noted that due to uncertainty in the environment it is quite difficult not only to gain, but also to maintain competitive advantage in the market. Therefore, competitive advantage as a phenomenon is being studied in scientific works quite generally and from various points of view.

Porter points out that competitive advantage is the advantage that company has over its competitors, stemming from company's unique value propositions as perceived by costumers in some market segments (Porter, 1985). In its own turn, the competitive advantage shows managers how to evaluate their competitive position and implement the specific action steps necessary to improve it. Thus M. Porter gives preference to the analysis of an industry (to five competitive forces).

Accordingly, Porter defines three generic strategies: cost leadership strategy, differentiation strategy and focus strategy which show how competitive advantage can be defined in terms of relative cost and relative prices. Therefore, the competitive advantage exists when company is able to deliver the same benefits as competitors but at a lower cost (cost advantage) or deliver benefits that exceed those of competing products (differentiation advantage).

It should be noted that companies supported by the government might have higher level of profits in certain business sectors even without trying to achieve advantage by low cost or differentiation. Therefore the low cost and differentiation are not the only factors determining the results. It is not accidental that other scholars more and more attention have been paid to the other factors of competitive advantage such as the speed at which a product reaches the market, flexibility of an organisation or combination of all these factors (Datar \& Jordan, 1997). Moreover, competitive advantage gained by the low cost and differentiation may be lost soon because companies, which have gained it, can maintain it until products or the technological methods correspond to the requirements of most consumers. Therefore the focus of scholars on a company's competitive advantage as its ability to change rather than occupy a position in the market, prompted the development of the resource-based view. Accordingly, „not only do external factors determine the firm's success and profitability but internal factors also play an important role" (Olalla, 1999). Besides that the resource-based view is considered to be the most appropriate concerning companies working in an uncertain environment when changes of consumers' tastes and technological innovations do not allow predicting the portfolio of products and market segments in the future (Azzone \& Bertele, 1995; Duncan \& Ginter, 1998). 


\section{The Influence of Other Theories on Resource-Based View}

It should be noted, that neoclassical microeconomics and evolution theories had the greatest influence on the development of the resource-based view. Neoclassical microeconomics focuses on how market forces determine the quantity, quality and price of goods. Essentially, this theory has many presumptions identical to the resource-based view. For instance, such statements as maximisation of profit and differences between markets in terms of competitiveness, and distribution of information are characteristic not only to neoclassical microeconomics, but also to the resource-based view. According to J. Barney, there is only one difference between these theories (Barney, 2001). Neoclassical microeconomics assumes that, as a matter of fact, the supply of resources and organisational capabilities is elastic, which means that when a demand for a certain resource increases, its price and the total amount of resources increases in the market. In its own turn, the resource-based view emphasizes that the supply of most production factors might be elastic, but some resources cannot be sold or bought, and the supply of certain production factors may be not elastic. A nonelastic supply means that companies that possess such resources and capabilities might achieve a higher profit level, and this profit does not stimulate a greater supply of resources and capabilities in the short-term and long-term perspective. Because of this reason a non-elastic supply may become the source of a longterm competitive advantage.

It is possible to claim that the resource-based view replaces the neoclassical microeconomics, i.e. theory explaining why competitive advantage may not be maintained is replaced by a theory explaining why this advantage may be maintained.

The authors analysing the relationship between the resource-based view and neoclassical microeconomics have attempted to evaluate in quantitative terms the resources and capabilities available to an organisation. However, the relationship between the resource-based view and neoclassical microeconomics does not explain how to maintain competitive advantage in a changing competitive environment and how to develop and advance capabilities; thus focus has shifted to the relationship between the resource-based view and the evolution theory.

It should be noted that the evolution theory connects the ideas of the natural selection of firms and of organisational genetics (Helfat, 1994). Thus like natural selection in biology, natural selection in economy depends on the external environment determining the survival and the growth of companies. Organisational genetics, in its own turn, analyses the transfer of organisational features in terms of time. As in biological evolution, changes occur in a constant cycle of deviation, choice and preservation (Van de Ven \& Poole, 1995). Besides that, this process is stimulated by competition between companies for limited resources.

R. Nelson and S. Winter claim that organisations that have to make decisions in a stable environment and realise changes in the same direction are more effective than those that have to cope with an uncertain environment and realise various new changes (Helfat, 1994).

According to R. Nelson and S. Winter, companies differ in their way of business development. Therefore, they become a fundamental object of study. Under competitive conditions some of those ways are more effective and productive than others. Thus the less effective ways are replaced, otherwise companies cease to exist in the long-term perspective. It is not accidental that the most effective and productive ways determine the company's competitive advantage. The results determined by the ways of business development guarantee survival and create a corresponding mechanism in a company, which, in its own turn, guarantees a long-term advantage. The scholars who have advanced the connection between the evolution theory and the resource-based view have been seeking to explain how company's capabilities change in time and what is the meaning of those changes. Nevertheless, despite linking the resource-based view both to neoclassical microeconomics and to the evolution theory, problems related to the strategic management of an organisation are still being solved ineffectively.

\section{Resource-Based View to Competitive Advantage}

The fundamental idea of the resource-based view is that a company has to advance its resources and capabilities constantly in order to gain a competitive advantage in an uncertain environment (Barney, 1991; Tallman \& Fladmoe-Lindquist, 2002). The main argument is that competitive advantage is, first of all, determined by the valuable resources of organisation, such as its collective capabilities and competence (Barney, 2001; Lopez, 2001). Lado and Wilson says: „The firm is viewed as a nexus of resources and 
capabilities that are not free bought and sold in the spot market. To the extent that these firm-specific resources and capabilities yield economic benefits that cannot be perfectly duplicated through competitors ${ }^{6}$ actions, they may be potent sources of sustained competitive advantage" (Lado \& Wilson, 1994).

In its own turn, the resource-based view has refuted the opinion that a company's potential and dangers should be assessed in terms of the product (Priem, 2001). It is necessary to point out that the conditions for the optimal growth of a company are created by properly balancing the use of available resources and development of new ones. (Ghemawat \& Costa, 1993). Therefore, a company seeking constant growth has to advance available resources and look for new ones constantly.

Moreover, there is an opinion that the unique resources of a company are directly related to its higher results. Unique, difficult to imitate and immobile resources are appreciated because they generate economical rent. The authors who have been developing this theory claim that the relationship between competitive advantage and results is obviously direct, because it does not make a precise distinction between low prices, differentiation or other types of competitive advantage. If a company has valuable, rare and difficult to emulate resources, higher results are guaranteed.

In terms of the resource-based view, strategic resources should meet certain criteria (Hunt, 1997). Very often resources available to a company and allowing it to create goods productively and present them effectively to the market, and thus create a greater value in a segment of market are tangible and intangible (Hunt \& Morgan, 1995). According to Wernerfelt „By a resource is meant anything which could be thought of as strength or a weakness of a given firm. More formally, a firm's resources at a given time could be defined as those (tangible and intangible) assets which are tied semi permanently to the firm. Examples of resources are: brand names, in-house knowledge of technology, employment of skilled personnel, trade contracts, machinery, efficient procedures, capital,..." (Wernerfelt, 1984). Hunt and Morgan point out that tangible resources may be grouped into financial, physical, legal, human, organisational, informational and relational resources (Hunt \& Morgan, 1995).

Financial resources include all monetary forms of a company's resources: cash reserve, invested capital, share capital etc.

Physical resources include long-term and immovable assets available to a company.
Legal resources include trade marks, licenses etc.

Human resources include employees' motivation, loyalty, knowledge and skills.

Organisational resources include company's structure, systems, processes and culture.

Informational resources include company's knowledge about its environment and competitors.

Relational resources include relationships with suppliers and customers.

In their own turn, essential capabilities of a company are ascribed to the intangible higher level resources allowing it to work better than do its competitors. According to Grant, resources are combined to create capabilities which are the basis for a competitive advantage (Grant, 1991). Such capabilities include: entrepreneurial capabilities, technical capabilities, organisational capabilities, management capabilities.

Entrepreneurial capabilities include: 1) ability to identify essential buyers; 2) ability to create new markets; 3) ability to identify new markets. A company in possession of such capabilities can expand effectively its business and adapt to the environment.

Technical capabilities include: 1) technical capabilities that stimulate creativity; 2) technical capabilities directed towards effectiveness; 3 ) technical capabilities directed towards flexibility; 4) technical capabilities granting quality.

Entrepreneurial capabilities help a company to identify customers and possibilities in the market; technical capabilities help to decide how the buyers' needs will be satisfied with the help of available technologies and production processes.

Organisational capabilities include: 1) organisational capabilities that increase creativity; 2) organisational capabilities that increase effectiveness; 3) organisational capabilities that increase quality; 4) organisational capabilities that grant speed and flexibility; 5) organisational learning. It should be noted that organisational capabilities help to mobilise the efforts of a company's employees in trying to reach their goals, encourage organisational learning, help to realise changes and complement technical skills.

Management capabilities include: 1) integration of various competencies; 2) versatile application of essential competencies to different product markets; 3) ability to change the configuration of essential competencies and application to new markets. While seeking to use opportunities in the market, 
management capabilities help a company to create, coordinate, integrate and change available competencies. These are the higher level capabilities helping to generate other capabilities and use them in a productive way.

Strategic resources should be heterogeneous and immobile. Heterogeneity means that every company has a certain collection of resources, which is, by the way, unique. Moreover, immobile resources guarantee that they will not be purchased or sold in the market easily. Thus a company possessing resources (or a specific collection of resources), remarkable for their heterogeneity and immobility among competitors, has a potential to gain a comparative advantage (Bharadwaj, Varadarajan \& Fahy, 1993). A comparative advantage in terms of resources exists when the collection of a company's resources allows the company to supply the market with products, which, compared to its competitors' products, have a higher value in certain segments of the market and may be produced at a higher cost. According to J. Barney, if resources are immobile, competitors tend to behave innovatively, i.e. try to emulate or seek substitute resources.

It is necessary to note that the resource-based view should be viewed as a structural and detailed conception explaining how and why it is possible to maintain the competitive advantage once achieved (Priem, 2001). Besides that, the resource-based view has little influence on studies trying to predict competitive advantage. Advantage may be identified only when it has already been achieved, but it cannot be predicted in terms of the resource-based view.
There is an opinion that the argument of conceptual scientific works would improve, if the researchers of company's strategy rejected the metaphor of "coin" suggested by Wernerfelt, according to which, one side of the coin represents a company's resources, and the other, the competitive environment. This concept of "the two sides of the coin" presents different opinions on a company"s resources and the competitive environment. However, such a distinction, although significant from the academic point of view, is insufficient in solving practical problems of strategic management because such an artificial distinction and the development of terminology it causes restricts the elaboration of the concept of strategy development. Andrews emphasizes that a competitive advantage depends on the relationship betveen environmental opportunities and a firm's distinctive competencies (Andrews, 1971). Therefore, resources define what a company can do, and the competitive environment defines what can be done in order to satisfy consumers' demands. These attitudes are of equal significance in development of a company's strategy leading to compatitive advantage.

\section{The Analytic Hierarchy Process}

One of the methods allowing to connect different attitudes and evaluate a company's competitive advantage in the segments of market is the Analytic Hierarchy Process (AHP).

The advantage of this method lies in the fact that it defines relative weights of a criterion, controls the integrity of paired comparisons; it is easy to add new elements to the hierarchy (Zavbi \& Duhovnik, 1996).

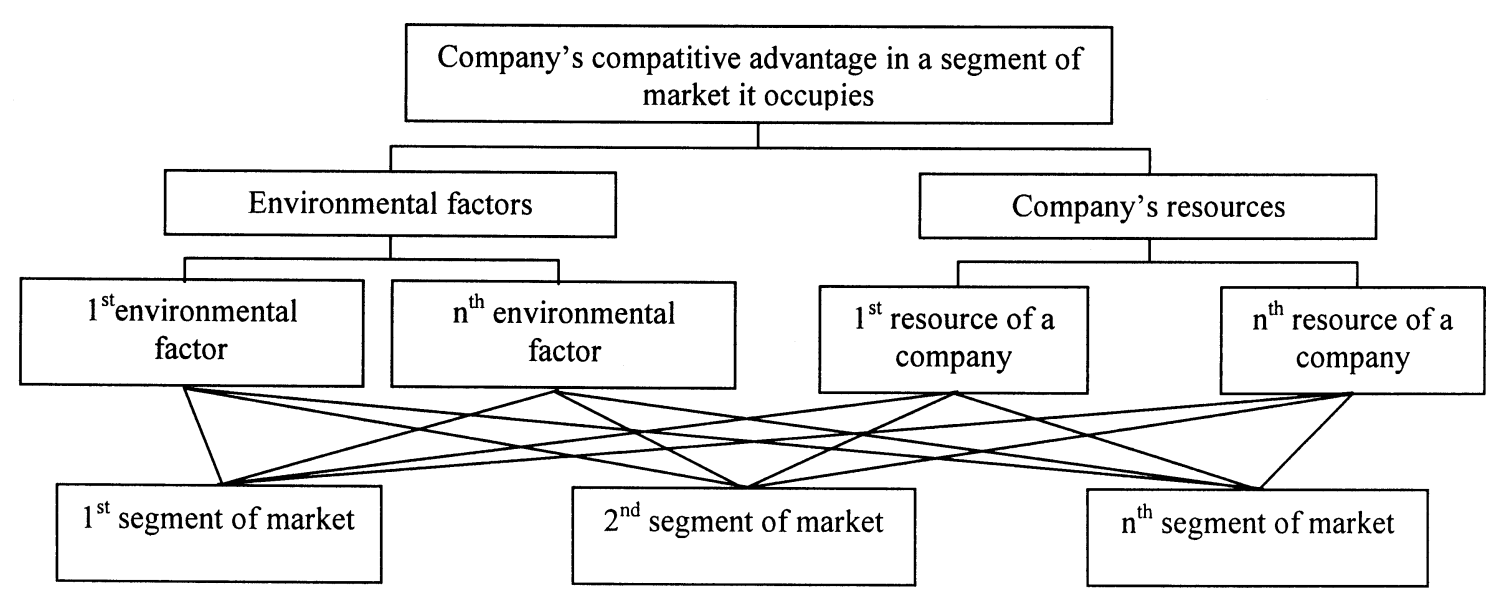

Fig 1. Hierarchy used to determine a company's advantage in the segments of market it occupies 
Quite often this method is used to define and compare the main elements affecting a company's most important strategic goals, while trying to gain advantage in the market (Putrus, 1992). Saaty points out that „to deal with complexity we need rationality, and that is best manifested in the analytical approach" (Saaty, 1994).

Thus a model for the determination of competitive advantage of the company is proposed (Fig. 1). The top level of the hierarchy reflects the overall objective. The second level represents criteria affecting the decision i.e. environmental factors and a company's resources.

The third level indicates how the environmental factors and resources available to the company affect the company's advantage in the segments of market it occupies. The fourth level comprises the corresponding segments of market.

The AHP is a systematic procedure representing the elements defining the essence of the problem hierarchically. It is possible, by applying decomposition, to divide a problem into simpler elements and analyse them further in pairs. Each set of elements are evaluated in a pairwise fashion using 9-point scale proposed by Saaty (Table 1).

Table 1. Definition of preferance ratings

\begin{tabular}{|l|l|}
\hline Importance & \multicolumn{1}{|c|}{ Definition } \\
\hline 1 & Equal importance \\
\hline 3 & Weak importance of one over the other \\
\hline 5 & Essential or strong importance \\
\hline 7 & $\begin{array}{l}\text { Very strong or demonstrated } \\
\text { importance }\end{array}$ \\
\hline 9 & Absolute importance \\
\hline $2,4,6,8$ & $\begin{array}{l}\text { Intermediate values between adjacent } \\
\text { scale variables }\end{array}$ \\
\hline
\end{tabular}

After the comparison of the elements in each level, the preference matrices are formed. These formed matrices creates preconditions to calculate and nomalize its principal eigenvector. This calculated and normalized eigenvector gives a set of the relative wights of attributes.

It should be noted that a consistency index (CI) should be calculated.

$$
C I=\frac{\lambda_{\max }-n}{n-1},
$$

here: $\lambda_{\max }$ the largest eigenvalue of the $n \times n$ reciprocal matrix.

The CI measures the relative closeness of $\lambda_{\max }$ to $n$. Therefore it accounts for the number of attributes by division by $n-1$. Saaty determined the average value of the CI and termed these average values RI (for random index) (Table 2).

Calculation of a consistency ratio (CR), defined as the ratio of the $\mathrm{CI}$ to the RI creates preconditions to judge the consistency of pairwise comparisons. According to Saaty, if CR values $>0.1$, the paired evaluations should be reworked.

\section{Determination of Competitive Advantage: A Case Study}

In testing the proposed model the company operating in electronics industry was chosen. It should be noted that for the sake of anonymity, the name of the company is disguised. The choice was influenced by the fact that the electronics industry should receive special attention due to economic and strategic reasons: this sector is characterised by high value added, labour force potential, knowledge intensity and rapidly growing global market, which is marked by the elasticity of income ( $\mathrm{Yu}, 1999)$. The electronics industry is remarkable for the growth of expenses for research and design as well as time needed for research and designing.

While defining its mission, the selected company takes into account the achievements and needs of the globally dominating companies and gives priority to innovations and traditions. In its attempt to fulfil the mission, the company's main task is investment into production systems, acquisition of the necessary knowhow and aspiration for a competitive advantage in global markets. Investment into production systems is related to the scale of production of goods; acquisition of the necessary know-how, to the advancement of essential technologies; competition in the market, to the choice of the segments of market and gaining a competitive advantage in these segments.

It should be noted that electronics industry is similar to other industrial markets dominated by several large international customers who affect the quality of any product and delivery requirements.

Table 2. Average values, termed RI, for $n=3-13$

\begin{tabular}{|c|c|c|c|c|c|c|c|c|c|c|c|}
\hline$n$ & 3 & 4 & 5 & 6 & 7 & 8 & 9 & 10 & 11 & 12 & 13 \\
\hline RI & 0.58 & 0.90 & 1.12 & 1.24 & 1.32 & 1.41 & 1.45 & 1.49 & 1.51 & 1.48 & 1.56 \\
\hline
\end{tabular}


In this case, the product's quality means not only the reliability of the product, but also the degree of meeting the criteria of its usage. The main customer defines the quality standards directly; both the producer and the costumer have to meet them. Although the organisations' attitudes differ during the early stages of the product life cycle, all producers should guarantee quality standards; in the opposite case, they would not be able to compete and would be excluded from the market.

The largest customers also influence prices, because the product of one producer is easily replaced by the product of another producer. Thus the main costumers raise similar requirements for prices to all suppliers. The only reason why the main customer have more than one supplier is their effort to avoid the inability of one source to supply a product when it is needed.

Obviously, quality elasticity and price elasticity are small in this sector, and competitors perceive supply as one of the ways to stand out among the others and thus gain a competitive advantage. Then the cycle of product development becomes an important part of all product life cycle, and competition among producers starts at the early phases of product development: generation of the concept, project studies, prototype, production and mass production.

Items produced by the selected company are classified as industrial-technical products; their groups are formed by the segments of market on the basis of their technical parameters. Therefore, it is quite easy to define four most important segments of market, which the enterprise is seeking an advantage in.

The management of the company agreed that the main environmental factors, influencing company's competitive advantage are as follows: the entry of competitors, the threat of substitutes, the bargaining power of buyers, the bargaining power of suppliers and the rivalry among the existing players. Also the group of managers reached a consensus that the main resources available to the company are as follows: technological resources and capabilities, human resources and capabilities, informational resources, financial resources, organizational resources and capabilities.

The next step in order to define the company's advantage in the segments of market it occupies, managers of company were asked to compare criteria in pairs and evaluate the answers by a relative value from the scale provided (Table 1).

Table 3 represents results of ranking internal and external factors, i.e. company's resources and environmental factors. The managers answer the question, Which factor is preferred most with respect to competitive advantage and how strongly? It should be noted that resources is much more preferred than environmental factors.

Table 4 shows results of ranking environmental factors, i.e. the entry of new competitors, the bargaining power of buyers, the threat of substitutes, the rivalry among the existing players and the

Table 3. Ranking internal and external factors. Which factor is preferred most with respect to competitive advantage and how strongly?

\begin{tabular}{|c|c|c|c|}
\hline & Environmental factors & Resources & Priorities \\
\hline Environmental factors & 1 & 0,33 & 0,25 \\
\hline Resources & 3 & 1 & 0,75 \\
& & & $\lambda_{\text {max }}=2,00 ;$ \\
& & & $\mathrm{CI}=0,00 ;$ \\
& & & $\mathrm{CR}=0,00$ \\
\hline
\end{tabular}

Table 4. Ranking environmental factors. Which factor is perferred most with respect to competitive advantage and how strongly?

\begin{tabular}{|c|c|c|c|c|c|c|}
\hline & $\begin{array}{c}\text { New } \\
\text { competitors }\end{array}$ & Buyers & Substitutes & $\begin{array}{c}\text { Existing } \\
\text { competitors }\end{array}$ & Suppliers & Priorities \\
\hline New competitors & 1 & 0,2 & 0,2 & 0,5 & 0,33 & 0,05 \\
\hline Buyers & 5 & 1 & 5 & 3 & 4 & 0,44 \\
\hline Substitutes & 5 & 0,2 & 1 & 0,33 & 0,5 & 0,10 \\
\hline Existing competitors & 2 & 0,33 & 3 & 1 & 6 & 0,29 \\
\hline Suppliers & 3 & 0,25 & 2 & 0,17 & 1 & $\begin{array}{c}0,12 \\
\lambda_{\max }=5,66 ; \\
\mathrm{CI}=0165 ; \\
\mathrm{CR}=0,147\end{array}$ \\
\hline
\end{tabular}


Table 5. Ranking company's resources. Which resource is preferred most with respect to competitive advantage and how strongly?

\begin{tabular}{|c|c|c|c|c|c|c|}
\hline & $\begin{array}{l}\text { Informational } \\
\text { resources }\end{array}$ & $\begin{array}{c}\text { Human } \\
\text { resources and } \\
\text { capabilities } \\
\end{array}$ & $\begin{array}{l}\text { Technological } \\
\text { resources and } \\
\text { capabilities } \\
\end{array}$ & $\begin{array}{l}\text { Financial } \\
\text { resources }\end{array}$ & $\begin{array}{l}\text { Organizational } \\
\text { resources and } \\
\text { capabilities } \\
\end{array}$ & Priorities \\
\hline $\begin{array}{l}\text { Informational } \\
\text { resources }\end{array}$ & 1 & 0,14 & 0,14 & 3 & 0,14 & 0,04 \\
\hline $\begin{array}{l}\text { Human resources } \\
\text { and capabilities }\end{array}$ & 7 & 1 & 0,33 & 7 & 0,2 & 0,16 \\
\hline $\begin{array}{l}\text { Technological } \\
\text { resources and } \\
\text { capabilities }\end{array}$ & 7 & 3 & 1 & 5 & 3 & 0,41 \\
\hline Financial resources & 0,33 & 0,14 & 0,2 & 1 & 0,11 & 0,03 \\
\hline $\begin{array}{l}\text { Organizational } \\
\text { resources and } \\
\text { capabilities }\end{array}$ & 7 & 5 & 0,33 & 9 & 1 & $\begin{array}{c}0,36 \\
\lambda_{\max }=554 ; \\
\mathrm{CI}=0,14 ; \\
\mathrm{CR}=0,12\end{array}$ \\
\hline
\end{tabular}

bargaining power of suppliers. The managers answer the question, Which factor is preferred most with respect to competitive advantage and how strongly? It should be noted that the bargaining power of buyers is much preferred than other factors.

Table 5 represents results of ranking company's resources, i.e. informational resources, human resources and capabilities, technological resources and capabilities, financial resources, organizational resources and capabilities. The managers answer the question, Which resource is preferred most with respect to competitive advantage and how strongly? It should be noted that technological resources and capabilities are much preferred than other resources.

Table 6 shows results of ranking company's segments of market with respect to such factors as the entry of new competitors, the bargaining power of buyers, the threat of substitutes, the rivalry among the existing players and the bargaining power of suppliers, resources, human resources and capabilities, technological resources and capabilities, financial resources, organizational resources and capabilities. Items produced by the selected company are classified as industrial-technical products; thus the segments of market are defined on the basis of the technical parameters of products. It should be noted that the segments of market are indicated by A, B, C and D.

After integrating local priorities the final results are presented in table 7 .

The results indicate that the advantage of the company is not the same in all segments of market. It is possible to claim that the company's competitive advantage is the greatest in the B segment of market and the smallest, in the D segment.
To sum it up, every organisation could apply the analytic hierarchy process for the determination of its competitive advantage. For this purpose, it has to take into account the forces of the external environment and company's resources and capabilities. After having determined its competitive advantage in the segments of market it occupies, the managers can make appropriate strategic decisions concerning further development in each segment.

\section{Conclusions}

From the above stated propositions, it is possible to make some conclusions and offer suggestions for further research.

In the context of fundamental changes initiated by globalisation, new technologies, intensive competition and fluctuating demand of consumers business organisations encounter the problem of competitive advantage, whose solution is closely related to the organisation's capacity to determine the competitive advantage it has gained. This means that competitive advantage is a promising subject for management studies requiring further research.

Despite the variety of approaches to competitive advantage in academic literature, this paper strssess that not only external factors determine the company's success and profitability but internal factors also play an important role. Thus the resource-based view should be estimated as a structural and detailed conception explaining how and why the acquired advantage may be preserved through constant advancement of the organisation's resources, capabilities and competencies. 
Table 6. Ranking segments of market

\begin{tabular}{|c|c|c|c|c|c|c|c|c|c|c|c|}
\hline $\begin{array}{c}\text { New } \\
\text { competitors }\end{array}$ & $\mathbf{A}$ & B & $\mathbf{C}$ & D & Priorities & $\begin{array}{l}\text { Informational } \\
\text { resources }\end{array}$ & $\mathbf{A}$ & B & $\mathbf{C}$ & D & Priorities \\
\hline $\mathbf{A}$ & 1 & 2 & 2 & 5 & 0,40 & $\mathbf{A}$ & 1 & 0,11 & 0,2 & 0,25 & 0,04 \\
\hline B & 0,5 & 1 & 3 & 9 & 0,41 & B & 9 & 1 & 2 & 7 & 0,51 \\
\hline $\mathbf{C}$ & 0,5 & 0,33 & 1 & 3 & 0,14 & $\mathbf{C}$ & 5 & 0,5 & 1 & 7 & 0,36 \\
\hline $\mathbf{D}$ & 0,2 & 0,11 & 0,33 & 1 & $\begin{array}{c}0,05 \\
\lambda_{\max }=4,08 \\
\mathrm{CI}=0,03 \\
\mathrm{CR}=0,03\end{array}$ & $\mathbf{D}$ & 4 & 0,14 & 0,14 & 1 & $\begin{array}{c}0,09 \\
\lambda_{\max }=4,22 \\
\mathrm{CI}=0,07 \\
\mathrm{CR}=0,08\end{array}$ \\
\hline Buyers & $\mathbf{A}$ & $\overline{\mathbf{B}}$ & $\bar{C}$ & $\overline{\mathbf{D}}$ & Priorities & $\begin{array}{l}\text { Human resources } \\
\text { and capabilities }\end{array}$ & $\overline{\mathbf{A}}$ & $\overline{\mathbf{B}}$ & $\bar{C}$ & $\overline{\mathbf{D}}$ & Priorities \\
\hline $\mathbf{A}$ & 1 & 0,11 & 0,11 & 0,13 & 0,02 & $\mathbf{A}$ & 1 & 0,13 & 0,14 & 0,33 & 0,04 \\
\hline B & 9 & 1 & 9 & 9 & 0,73 & B & 8 & 1 & 3 & 7 & 0,59 \\
\hline $\mathbf{C}$ & 9 & 0,11 & 1 & 3 & 0,17 & $\mathbf{C}$ & 7 & 0,33 & 1 & 4 & 0,28 \\
\hline D & 8 & 0,11 & 0,33 & 1 & $\begin{array}{c}0,08 \\
\lambda_{\max }=4,33 \\
\mathrm{CI}=0,11 \\
\mathrm{CR}=0,12\end{array}$ & D & 3 & 0,14 & 0,25 & 1 & $\begin{array}{c}0,09 \\
\lambda_{\max }=4,02 \\
\mathrm{CI}=0,01 \\
\mathrm{CR}=0,01\end{array}$ \\
\hline Substitutes & $\bar{A}$ & $\bar{B}$ & $\bar{C}$ & $\overline{\mathbf{D}}$ & Priorities & $\begin{array}{l}\text { Technological } \\
\text { resources and } \\
\text { capabilities }\end{array}$ & $\overline{\mathbf{A}}$ & $\overline{\mathbf{B}}$ & $\bar{C}$ & $\bar{D}$ & Priorities \\
\hline A & 1 & 0,11 & 0,14 & 0,2 & 0,03 & - & 1 & 0,14 & 0,2 & 0,33 & 0,04 \\
\hline B & 9 & 1 & 4 & 7 & 0,61 & B & 7 & 1 & 6 & 7 & 0,67 \\
\hline $\mathbf{C}$ & 7 & 0,25 & 1 & 5 & 0,27 & $\mathrm{C}$ & 5 & 0,17 & 1 & 3 & 0,2 \\
\hline D & 5 & 0,14 & 0,2 & 1 & $\begin{array}{c}0,09 \\
\lambda_{\max }=4,21 \\
\mathrm{CI}=0,07 \\
\mathrm{CR}=0,08\end{array}$ & D & 3 & 0,14 & 0,33 & 1 & $\begin{array}{c}0,09 \\
\lambda_{\max }=4,13 \\
\mathrm{CI}=0,04 \\
\mathrm{CR}=0,05\end{array}$ \\
\hline $\begin{array}{c}\text { Existing } \\
\text { competitors }\end{array}$ & $\bar{A}$ & $\overline{\mathbf{B}}$ & $\bar{C}$ & $\overline{\mathbf{D}}$ & Priorities & $\begin{array}{l}\text { Financial } \\
\text { resources }\end{array}$ & $\overline{\mathbf{A}}$ & $\overline{\mathbf{B}}$ & $\bar{C}$ & $\overline{\mathbf{D}}$ & Priorities \\
\hline $\mathbf{A}$ & 1 & 0,11 & 0,11 & 0,11 & 0,02 & $\mathbf{A}$ & 1 & 0,50 & 0,50 & 3 & 0,19 \\
\hline B & 9 & 1 & 6 & 8 & 0,64 & B & 2 & 1 & 2 & 8 & 0,51 \\
\hline $\mathrm{C}$ & 9 & 0,17 & 1 & 5 & 0,25 & $\mathbf{C}$ & 2 & 0,50 & 1 & 6 & 0,24 \\
\hline D & 9 & 0,13 & 0,20 & 1 & $\begin{array}{c}0,09 \\
\lambda_{\max }=4,56 \\
\mathrm{CI}=0,18 \\
\mathrm{CR}=0,20\end{array}$ & D & 0,33 & 0,13 & 0,17 & 1 & $\begin{array}{c}0,06 \\
\lambda_{\max }=4,06 \\
\mathrm{CI}=0,02 \\
\mathrm{CR}=0,02\end{array}$ \\
\hline Suppliers & $\overline{\mathbf{A}}$ & $\overline{\mathbf{B}}$ & $\bar{C}$ & $\overline{\mathbf{D}}$ & Priorities & $\begin{array}{l}\text { Organizational } \\
\text { resources and } \\
\text { capabilities }\end{array}$ & $\overline{\mathbf{A}}$ & $\bar{B}$ & $\bar{C}$ & $\overline{\mathbf{D}}$ & Priorities \\
\hline $\mathbf{A}$ & 1 & 0,11 & 0,14 & 0,2 & 0,03 & $\mathbf{A}$ & 1 & 0,13 & 0,14 & 0,33 & 0,04 \\
\hline B & 9 & 1 & 4 & 8 & 0,61 & B & 8 & 1 & 7 & 8 & 0,69 \\
\hline $\mathrm{C}$ & 7 & 0,25 & 1 & 5 & 0,27 & $\mathrm{C}$ & 7 & 0,14 & 1 & 5 & 0,21 \\
\hline D & 5 & 0,13 & 0,20 & 1 & $\begin{array}{c}0,09 \\
\lambda_{\max }=4,29 \\
\mathrm{CI}=0,10 \\
\mathrm{CR}=0,11\end{array}$ & D & 3 & 0,13 & 0,20 & 1 & $\begin{array}{c}0,06 \\
\lambda_{\max }=4,34 \\
\mathrm{CI}=0,11 \\
\mathrm{CR}=0,12\end{array}$ \\
\hline
\end{tabular}


Table7. The final results

\begin{tabular}{|c|c|c|c|c|c|c|c|c|c|c|c|}
\hline $\begin{array}{c}\text { Segments } \\
\text { of market }\end{array}$ & $\begin{array}{c}\mathbf{1} \\
(0,05)\end{array}$ & $\begin{array}{c}\mathbf{2} \\
(0,44)\end{array}$ & $\begin{array}{c}\mathbf{3} \\
(0,10)\end{array}$ & $\begin{array}{c}\mathbf{4} \\
(0,29)\end{array}$ & $\begin{array}{c}\mathbf{5} \\
(0,12)\end{array}$ & $\begin{array}{c}\mathbf{6} \\
(0,04)\end{array}$ & $\begin{array}{c}\mathbf{7} \\
(0,16)\end{array}$ & $\begin{array}{c}\mathbf{8} \\
(0,41)\end{array}$ & $\begin{array}{c}\mathbf{9} \\
(0,03)\end{array}$ & $\mathbf{1 0}$ & $\begin{array}{c}\text { Gloabl } \\
\text { priorities }\end{array}$ \\
\hline A & 0,40 & 0,02 & 0,03 & 0,02 & 0,03 & 0,04 & 0,04 & 0,04 & 0,19 & 0,04 & 0,12 \\
\hline B & 0,41 & 0,73 & 0,61 & 0,64 & 0,61 & 0,51 & 0,59 & 0,67 & 0,51 & 0,69 & 0,44 \\
\hline C & 0,14 & 0,17 & 0,27 & 0,25 & 0,27 & 0,36 & 0,28 & 0,20 & 0,24 & 0,21 & 0.29 \\
\hline D & 0,05 & 0,08 & 0,09 & 0,09 & 0,09 & 0,09 & 0,09 & 0,09 & 0,06 & 0,06 & 0.15 \\
\hline
\end{tabular}

In order to relate two concepts and to determine a competitive advantage of company managers may use the analytic hierarchy process, which allows to represent the elements defining the essence of the problem hierarchically, to add new elements to hierarchy or to remove inessential elements. Therefore a hierarchy constructed in this way could be easily modified and applied practically.

A hierarchy was formed considering the recommendations provided by the analytic hierarchy process and the company's environment as well as resources and capabilities available to it, which allows us to determine the company's competitive advantage in the segments of market it occupies. It should be noted that the results obtained in such a way may help to take an appropriate strategic action steps or development of company's strategy.

\section{References}

Anderson, C. R. \& Paine, F. T. Managerial perceptions and strategic behavior. Academy of Management Journal, 18, 1975, p. 811-823.

Andrews K. The Concept of Corporate Strategy. Homewood, IL Dow Jones-Irwin 1971.

Azzone, G.; Bertele, U. Measuring resources for supporting resource-based competition. Management Decision, 33, 9, 1995, p. 57-62.

Barney, Jay B. Resoursce - based theories of competitive advantage: A ten - year retrospective on the resourcebased view. Journal of Management, 27, 2001, p. 643650 .

Barney J. B. Firm resources and sustained competitive advantage. Journal of Management, 17, 1991, p. 99120.

Bharadwaj, Sundar G., Varadarajan, P.Rajan \& Fahy, John. Sustainable competitive advantage in service industries: a conceptual model and research propositions. Journal of Marketing, 57, 1993, p. 83-89.

Datar, S.; Jordan, S. Advantages of time - based new product development in a fast - cycle industry. JMR:
Journal of Marketing Research, 34, 1, 1997, p. 36-49.

Duncan, W.; Ginter, P. Competitive advantage and internal organizational assessment. Academy of Management Executive, 12, 3, 1998, p. 6-16.

Ghemawat, P.\&Costa, J. The organizational tension between static and dynamic efficiency. Strategic Management Journal (winter special issue), 1993, p. 59-73.

Grant, R.M. The Resource-Based Theory of Competitive Advantage: Implications for Strategy Formulation. California Management Review, 33, 3, 1991, p. 114135.

Helfat, Constance E. Evolutionary trajectories in petroleum firm R\&D. Management Science, 40, 12, 1994, p. 1720 1747.

Hunt, Shelby D,\& Morgan, Robert M. The comparative advantage theory of competition. Journal of Marketing, 59,1995 , p. $1-15$.

$\mathrm{Yu}$ S. The growth pattern of Samsung electronics. International Studies of Management and Organization, 28, 4, 57, 1998-1999.

Lado, A.A.; Wilson, M.C. Human resource Systems and Sustained Competitive advantage: A Competency-Based perspective. Academy of Management Review, 19,4, 1994, p. 699-727.

Lopez, Vicente, A. An overview review of the resourcebased view (RBV) of the firm, drawing on recent Spanish management research. Irish Journal of Management, 22, 2, 2001, p. 105-120.

Milliken, F.J. Three types of perceived uncertainty about the environment: State, effect, and response uncertainty. Academy of Management Review, 12, 1987, p. 133-143.

Miller, D.\&Friesen, P.H. Strategy-making and environment: The third link. Strategic Management Journal, 4, 1983, p. 221-235.

Olalla, Marta Fossas. The Resource-based Theory and Human Resources. International Advances in Economic Research, 5, 1, 1999, p. 84-92.

Porter, M. Competitive advantage. N.Y.: London: Free Press Collier Macmillan, 1985.

Priem, Richard L. Is the resousrce-based "view" a useful perspective for strategic management research? Academy of Management Review., 26, 1, 2001, p. 22-40. 
Priem, Richard L. Tautology in the resource-based view and the implications of externally determined resource value: further comments. Academy of Management Review, 26, 1, 2001, p. 57-66.

22. Putrus R. Outsourcing analysis and justification using AHP. Information Strategy: The Executive's Journal, 9, 1, 1992, p. 31-37.

23. Saaty, Thomas L. How to make a Decision: The Analytic Hierarchy Process, Interfaces, 24,6, 1994, p. 19-44.

24. Tallman, Stephen; Fladmoe-Lindquist, Karin. Internationalization, globalization and capability-based strategy. California Management Review, 45, 12002.

25. Thompson, J.D. Organizations in action. N.Y.: McGrawHill, 1967.

26. Van De Ven, Andrew H.; Poole, Marshall Scott. Explaining development and change in organizations. Academy of Management Review, 20, 3, 1995, p. 510540.

27. Wernerfelt B. A Resource-Based View of the Firm. Strategic Management Journal, 5, 1984, p. 171-180.

28. Zavbi R., Duhovnik J. The analytic hierarchy process and functional appropriateness of components of technical systems. Journal of Engineering Design, 7, 3, 1996, p. 313-328. 